\title{
SUMARNO-ANALITIČKI INVENTAR FONDA ŽELJEZNIČKI TEHNIKUM PULA 1947. - 1953.
}

Jasna MRKONJIĆ

Državni arhiv u Pazinu

Pazin, Vladimira Nazora 3

jasna.mrkonjic@dapa.hr
UDK 377.36:656.2>(497.571Pula)

(083.22)“1947/1953“"

Stručni rad

Arhivski fond HR-DAPA-257 Željeznički tehnikum Pula sadrži gradivo nastalo u razdoblju od 1947. do 1953. godine. Gradivo Fonda popisano je i sređeno 2014. godine kad je izrađen i sumarno-analitički inventar. Pri opisivanju Fonda korišten je višerazinski sustav opisivanja s ciljem lakšeg predočavanja sadržaja gradiva te pružanja informacija korisnicima, kako o stvaratelju, tako i o gradivu. U inventaru su sadržani podatci o općem kontekstu u razdoblju djelovanja stvaratelja, što je utjecalo na njegov rad, a odnosi se na prikaz složenih poratnih okolnosti na području Istre.

Ključne riječi: Željeznički tehnikum Pula, Istra, sumarno-analitički inventar, arhivski fond

Keywords: Railroad Technical School, Istria, summary and analytical inventory, archival fonds

Parole chiave: Željeznički tehnikum (Scuola superiore tecnica di Pola), Istria, inventario sommario analitico, fondo archivistico

\section{ARHIVISTIČKI OPIS FONDA \\ HR-DAPA-257 ŽELJEZNIČKI TEHNIKUM PULA}

\section{IDENTIFIKACIJA}

\section{Identifikacijska oznaka / signatura}

HR-DAPA-257 


\section{Naslov}

Željeznički tehnikum Pula

\section{Vrijeme nastanka gradiva}

$1947-1953$

\section{Razina opisa}

Fond

\section{Količina i nosač jedinice opisa}

70 knjiga $^{1}, 82$ kutije, 9,30 d/m

\section{KONTEKST}

\section{UPRAVNA POVIJEST STVARATELJA I POVIJEST FONDA}

\section{Stvaratelj}

Željeznički tehnikum Pula

\section{Normirani oblik naziva}

Željeznički tehnikum Pula

\section{Razdoblje djelovanja stvaratelja}

1945. - 1953.

\section{Sjedište}

Pula

\section{Pravni položaj}

Srednja stručna škola

\section{Funkcije i djelatnost}

Željeznički tehnikum u Puli bio je stručna obrazovna ustanova. Kao jedan od prioritetnih zadataka u poratnoj izgradnji i obnovi zemlje nametnuta je potreba stvaranja

1 Navedeni podatci o broju knjiga u području Identifikacije prikazuju izvornu količinu gradiva nastalu djelatnošću stvaratelja. Tijekom tehničkoga opremanja gradiva, knjige su pohranjene u kutije, osim u nekoliko slučajeva, te prikazani podatci o količini gradiva na razini serija - podserija iskazuju takvo stanje, ali se i dalje radi o istoj ukupnoj količini knjiga/gradiva. 
obrazovanog, stručnog kadra različitih profila. Zadaća je budućih mladih stručnjaka podrazumijevala ugradnju stečenih stručnih znanja i vještina u sva područja gdje je postojala potreba, a uzevši u obzir činjenicu da se radilo o ratom devastiranoj zemlji, slabih gospodarskih dometa, koja je i prije rata bila slabo razvijena, zadatak je ozbiljnije shvaćen. Obnova i izgradnja infrastrukturne mreže željezničkih i cestovnih komunikacija nužno je zahtijevala odgovarajući stručni ljudski potencijal koji će moći odgovoriti postavljenim izazovima. U tom je smislu Željeznički tehnikum u Puli upravo kao obrazovna ustanova/ kadrovska srednja stručna škola, jedinstvena za područje tadašnje FNRJ, izobrazbom polaznika osiguravao kadrovsku jezgru za potrebe obnove i osposobljavanja željezničke prometne infrastrukture te je stvoreni stručni kadar na određeni način bio izravno ulaganje u buduću obnovu zemlje. Školovanjem stručnjaka različitih profila, kojih u zemlji nakon rata ni približno nije bilo dovoljno, prvenstveno se razmišljalo o potrebama nesmetanoga funkcioniranja željeznice kao osnovnoga i najdostupnijeg načina transporta ljudi, dobara, sirovina, jednom riječju svega što je potrebno u procesu pokretanja gospodarstva neke zemlje. Školovani je stručni kadar, iako je prvenstveno trebao biti usmjeren na potrebe željeznice, svoju praktičnu primjenu mogao imati i u drugim područjima, s obzirom na struke za koje je školovan, a to su bile industrijsko-tehnička (sa smjerovima strojarski, elektrotehnički, građevinski i elektroveza) te prometna, rudarska i metalska struka.

\section{Izvori ovlasti}

Djelatnost je Željezničkoga tehnikuma temeljena na sljedećim saveznim zakonima:

- Ukaz o osnivanju Ministarstva željeznica i Ministarstva saobraćaja Vlade FNRJ iz dosadašnjeg Ministarstva saobraćaja Vlade FNRJ (Sl. list FNRJ, Beograd, br. 108/48)

- Ukaz o reorganizaciji Vlade FNRJ (Sl. list FNRJ, Beograd, br. 18/51)

- Zakon o petogodišnjem planu za razvitak narodne privrede (Sl. list FNRJ, Beograd, br. 61/47)

- Ustav FNRJ (Sl. list FNRJ, Beograd, br. 10/46)

- Opća uredba o komitetima Vlade FNRJ (Sl. list FNRJ, Beograd, br. 32/46)

- Zakon o promjeni naziva narodnooslobodilačkih odbora (NN NRH 3/45).

\section{Unutarnji ustroj}

\section{Shematizam Željezničkoga tehnikuma}

Izmjenama školskog obrazovnog sustava 1947. godine dolazi do formiranja (željezničkih) tehnikuma, kao posebnih obrazovnih centara, u kojima je predviđeno školovanje budućega stručnog kadra, prvenstveno za potrebe željeznice u FNRJ, ali i općenito, neovisno o samoj željeznici. Željeznički tehnikum u Puli započeo je s radom početkom školske 1947./1948. godine, 10. 9. 1947. ili 28. 10. 1947., a prestao je s radom krajem školske 1952./1953. godine. Nakon odlaska savezničke vojske iz Pule bilo je dovoljno smještajnih kapaciteta za organiziranje nastave i smještaj učenika te se prvenstveno koristio prostor 
bivše vojarne Monte Zaro i hotela Riviera u Puli. Željeznički tehnikum bio je zavod čiji je glavni zadatak bio izgradnja stručnih kadrova, u obrazovnom stručnom smislu, te njihov odgoj. S obzirom na smještajne mogućnosti, u pojedinim je školskim godinama u nastavnom procesu sudjelovalo i do 2400 učenika, raspoređenih unutar 56 odjeljenja. Tijekom nekoliko godina djelovanja u Puli, kroz školu je prošlo oko 4600 učenika, što je ovu obrazovnu ustanovu činilo jedinstvenom u okvirima tadašnje države, i po broju učenika, i po koncepcijskim postavkama same škole, čija je temeljna zadaća bila proizvodnja stručnoga kadra, čija će se znanja iskoristiti odmah po završetku školovanja za potrebe tehnološkoga i društvenog napretka zemlje u izgradnji. Tako je osposobljeno oko 1200 prometnih tehničara, 900 elektrotehničara, 700 strojarskih tehničara i 180 časnika za vojsku. U okolnostima tadašnje neizvjesne političke situacije pograničnoga dijela teritorija u Istri, paralelno su vođene dvije različite školske politike u Zoni A i Zoni B, koja se nakon 1950. godine sve više prilagođavala jugoslavenskom modelu.

Nakon pripojenja Istre Hrvatskoj, željeznicu je napustio talijanski stručni kadar te je 1946. godine bilo organizirano školovanje za prometnike u Podbrdu (Slovenija) gdje se školovalo i 60-ak Istrana, dok su se strojovođe školovale u Kastvu i Mariboru.

\begin{tabular}{|c|c|c|}
\hline SHEMA ŠKOLE & SHEMA INTERNATA & RADNA MJESTA/SEKTORI \\
\hline Direktor Škole & Direktor Internata & Sekretarijat \\
\hline Zamjenik direktora & $\begin{array}{l}\text { Zamjenik direktora po vaspitnoj } \\
\text { službi }\end{array}$ & Personalna služba \\
\hline Saobraćajno-tehnički odsjek & Šef personalne službe & Vaspitna služba \\
\hline Ekonomski odsjek & Sekretar Internata & \\
\hline Mašinski odsjek & $\begin{array}{l}\text { Šef MTS (mašinsko-tehničko- } \\
\text { strojarski ekonomat) }\end{array}$ & MTS (ekonomat) \\
\hline Tehnički odsjek & Računovođa & Računovodstvo \\
\hline Obični radnici & Šef ekonomije & \begin{tabular}{|l|} 
Radiona \\
Kuhinja \\
\end{tabular} \\
\hline $\begin{array}{l}\text { Školske radionice pri } \\
\text { građevinskom i mašinskom } \\
\text { odsjeku }\end{array}$ & & Čistačice \\
\hline Honorarni službenici & & Ekonomija \\
\hline $\begin{array}{l}\text { Honorarni nastavnici pri } \\
\text { školskoj radionici }\end{array}$ & & Vešeraj/Pegleraj \\
\hline $\begin{array}{l}\text { Kvalificirani radnici pri školskoj } \\
\text { radionici }\end{array}$ & & Restoran \\
\hline
\end{tabular}

Prema Dinamičkom planu radne snage za 1950. godinu, ${ }^{2}$ koji je izradila JDŽ za potrebe Planske komisije Grada Pule, sukladno Odluci o sistematizaciji radnih i službenih mesta koju je donijela Komisija Ministarstva željeznica FNRJ br. 382/50 od 12. 3. 1950. godine, predviđen je porast sveukupnoga broja zaposlenih s početnih 141 na 149 unutar 1950. go-

2 Državni arhiv u Pazinu, HR-DAPA-978 Školski komitet KPH Željeznički tehnikum Pula, 1947-1953, 1.1.2 Zapisnici, izvještaji i planovi rada Komiteta, 1.1.2.2 Dinamički plan radne snage za 1950. pov. br. 40/50 od 9. 5. 1950., kut. 1. 
dine, odnoseći se na inženjersko-tehničko i administrativno osoblje, kvalificirane, nekvalificirane radnike, pomoćno osoblje i učenike. Sukladno stručnoj spremi, odnosno kvalifikacijama, taj je ljudski potencijal bio raspoređen na odgovarajuća radna mjesta/sektore, što je posredno utjecalo i na brojčano stanje i strukturu kadrova te na njihova zaduženja.

\section{Opći kontekst}

Zakonom o promjeni naziva narodnooslobodilačkih odbora od 25. 7. 1945. oni postaju narodni odbori, hijerarhijski ustrojeni te raspoređeni na području NRH. Na području Istre situacija je bila nešto drugačija, s obzirom na specifičnost situacije na terenu. Po prestanku rata Pula s okolicom našla se pod angloameričkom okupacijom od 16. 6. 1945. do 1947. godine. Međutim, za to vrijeme u gradu, praktički u ilegalnim uvjetima, djeluje i Gradski narodnooslobodilački odbor Pula. Ranije navedenim Zakonom od 25. 7. 1945. i narodnooslobodilački odbori s područja Istre sukladno novonastalim okolnostima, odnosno okončanjem ratnih aktivnosti, mijenjaju svoje nazive i postaju narodni odbori mijenjajući ujedno i svoju dotadašnju primarnu funkciju borbenoga djelovanja. Prestankom rata narodni odbori postaju organi civilne vlasti te se njihovi zadatci i obveze usmjeravaju na organiziranje života u novim, poratnim, civilnim uvjetima.

Kraj je rata Istra dočekala s teritorijalnom podjelom na sljedeće kotareve: Buje, Buzet, Čepić, Kras, Labin, Lošinj, Motovun, Pazin, Poreč, Rovinj, Tinjan, Umag, Vodnjan i Žminj, ukupno 14. U razdoblju od listopada 1947. do konačnoga integriranja u područje NRH došlo je do smanjenja broja kotareva na području Istre te se tako 1945. godine ukidaju kotarevi: Čepić, Rovinj, Tinjan i Umag, dok je kotar Žminj - Kanfanar ukinut 1946., a kotar Motovun 1947. godine. Sve su navedene teritorijalne izmjene izvršene prije listopada 1947. godine što je značilo da je područje Istre prije povezivanja s ostatkom zemlje bilo u jednom razdoblju administrativno organizirano u preko 7 kotarskih narodnih odbora te 3 gradska narodna odbora, unutar kojih je djelovalo 575 mjesnih narodnih odbora. U svom dopisu od 22. 7. 1946. Oblasni narodni odbor za Istru (dalje ONO za Istru) poimenično navodi popis istarskih mjesnih narodnih odbora s područja svoje nadležnosti, a koji su bili raspoređeni unutar 11 kotareva te područja nadležnosti Gradskoga narodnog odbora Rovinj. Tadašnjim administrativnim ustrojem Istre, navedenih 575 mjesnih narodnih odbora bilo je raspoređeno unutar sljedećih kotareva: Buje 48, Buzet 80, Cres 12, Kanfanar 60, Labin 66, Lošinj 11, Motovun 39, Opatija 50, Pazin 97, Poreč 63, Vodnjan 45, Gradski NO Rovinj.

Na sjednici od 1. 9. 1947. ONO za Istru odlučio je da se i na području Istre počinju primjenjivati svi važeći pravni propisi koji su vrijedili u FNRJ i NRH. Na izvanrednom zasjedanju ONO-a za Istru u Pazinu je također istoga dana, poštujući volju naroda Istre, na slobodnim izborima za Oblasnu narodnu skupštinu, koji su održani 25. 11. 1945., odlučeno da se teritorij Istre priključi matičnom području, odnosno području NRH, unutar zajedničke državne tvorevine FNRJ. Ukazom o proširenju važnosti Ustava, zakona i drugih propisa NRH na području Istre, gradova Rijeke i Zadra te otoka Lastova, tek su od 1. 10. 1947. ova područja navedena u sastavu NRH. Nadalje, Ukazom o priznavanju narodnih odbora 
na području Istre, gradova Rijeke i Zadra te otoka Lastova zakoniti su organi vlasti konačno i istarski narodni odbori, naslijedivši one nastale u ratu, te su dobili svoj zakonski legitimitet. ONO za Istru prestao je djelovati 30. 11. 1947. jer više nisu postojali opravdani razlozi za njegovo produženo djelovanje, zato što je Istra integrirana u područje NRH.

Zatečena je lokalna podjela unutar istarskoga teritorija svoju potvrdu dobila i na široj, republičkoj razini, Zakonom o izmjenama i dopunama Zakona o administrativno-teritorijalnoj podjeli NRH od 28. 6. 1947. godine.

Formiranjem Narodnoga odbora Grada Pule, kao legitimnoga i jedinog upravnog tijela za područje Pule, nakon prestanka savezničke okupacije počinje uspostava normalnih životnih tijekova, usmjerenih na poboljšanje općih životnih uvjeta u punom opsegu civilnoga života, što se na svoj način odrazilo i na području školstva.

Sukladno tome, u poslijeratnim promišljanjima i postavkama socijalističkoga napretka i razvitka zemlje, tehničko je obrazovanje mladih kadrova, stručnjaka različitih profila, prepoznato kao ključan trenutak i preduvjet bržega razvoja nerazvijene i ratom opustošene zemlje. U takvim se okolnostima, a bez dovoljnoga broja vlastitih kadrova, koji bi svojim znanjem i stručnošću na svojim radnim mjestima doprinosili općem napretku zemlje, nije moglo računati na ozbiljnije rezultate. Stoga je zanimanje za raznovrsne tehničke vještine bilo snažno podržano i vrlo ozbiljno razmatrano te prihvaćeno u visokim društvenim strukturama odlučivanja. Narodna tehnika (dalje NT), kao nov fenomen, nije nastala obnovom predratnih tehničkih organizacija, a ni po uzoru na strane modele sličnoga tipa, već je nastajala i razvijala se svojim putem, u uvjetima postupne obnove i poratnoga razvitka zemlje, s glavnim ciljem širenja osnovnoga tehničkog znanja. Radilo se o, uvjetno rečeno, specifičnoj organizaciji novoga tipa, koja daleko nadilazi uske školske stručne okvire jer se radilo o daleko širem društveno postavljenom planu.

Zbog brza je napretka pojedinih tehničkih grana stvorena potreba za formiranjem posebne komisije, odgovorne za rukovođenje radom Tehnike i sporta (dalje TS). Na II. Saveznom savjetovanju republikanskih komisija i Komisije Jugoslavije, održanom 12. 8. 1947. u Beogradu, postavljeni su temelji buduće organizacije Narodne tehnike (dalje NT) te je izvučeno nekoliko osnovnih zaključaka:

1. bez radionica nema ni mogućnosti za postojanje NT-a

2. planski je rad osnova NT-a.

Postavkama petogodišnjih planova - petoljetki težilo se bržem i mjerljivom napretku i njegovu praćenju, s osnovnim ciljem nadvladavanja tehnološke i privredne zaostalosti zemlje.

Masovnost, odnosno pristupačnost širokim masama zainteresiranih te uspjesi ostvareni pod okriljem organizacije TS-a, doveli su do potrebe njezina reorganiziranja i stvaranja samostalne, nove masovne organizacije, a što je i potvrđeno na I. Saveznoj konferenciji, 
održanoj u ožujku 1947. Tom je prigodom donesen i privremeni Statut NT-a te se formiraju tehnički klubovi po tvornicama, poduzećima, školama, zadrugama itd. ${ }^{3}$

Prvi Kongres NT-a održan je u Beogradu 1949. godine, a formiran je i Inicijativni odbor koji je bio zadužen za rukovođenje organizacijom NT-a te je kao takav djelovao do osnivačke skupštine kluba NT-a održane u svibnju 1949. na kojoj je izabrano rukovodstvo od 11 članova. Dotadašnje rukovodstvo nije bilo upućeno u rad NT-a te je, s obzirom na sve veću masovnost organizacije, novo i stručno rukovodstvo bilo prijeko potrebno.

Što se tiče NT-a u Željezničkom tehnikumu u Puli, početkom 1949. godine djelovalo je nekoliko kružoka, od kojih je radioamaterski bio najbolji. U samom je Željezničkom tehnikumu oformljen i Školski odbor NT-a, a postupno se organiziraju i školski klubovi. Tijekom 1949. godine školska organizacija NT-a okupljala je 2038 članova te 1986 omladinaca angažiranih preko sljedećih klubova: radioklub, fotoklub i kinoamateri, automotodruštvo, aeroklub (uključujući jedriličare, padobrance, modelatore).

\section{VEZE}

\begin{tabular}{|c|c|c|}
\hline Prva veza & \multirow{5}{*}{$\begin{array}{l}\text { Normirani oblik naziva } \\
\text { Ostali oblici naziva }\end{array}$} & \\
\hline $\begin{array}{l}\text { Naziv/oznaka povezanoga } \\
\text { entiteta }\end{array}$ & & $\begin{array}{l}\text { Oblasni narodni odbor za Istru } \\
\text { ONO za Istru }\end{array}$ \\
\hline Vrsta veze & & Hijerarhijska \\
\hline Opis veze & & Nadređeno tijelo \\
\hline Nadnevci veze & & 1947 \\
\hline \multicolumn{3}{|l|}{ Druga veza } \\
\hline $\begin{array}{l}\text { Naziv/oznaka povezanoga } \\
\text { entiteta }\end{array}$ & $\begin{array}{l}\text { Normirani oblik naziva } \\
\text { Ostali oblici naziva }\end{array}$ & $\begin{array}{l}\text { Gradski narodni odbor Pula } \\
\text { GNO Pula }\end{array}$ \\
\hline Vrsta veze & & Hijerarhijska \\
\hline Opis veze & & Nadređeno tijelo \\
\hline Nadnevci veze & & $1947-1953$ \\
\hline \multicolumn{3}{|l|}{ Treća veza } \\
\hline $\begin{array}{l}\text { Naziv/oznaka povezanoga } \\
\text { entiteta }\end{array}$ & $\begin{array}{l}\text { Normirani oblik naziva } \\
\text { Ostali oblici naziva }\end{array}$ & $\begin{array}{l}\text { Jugoslavenske državne željeznice } \\
J D R\end{array}$ \\
\hline Vrsta veze & & Hijerarhijska \\
\hline Opis veze & & Nadređeno tijelo \\
\hline Nadnevci veze & & $1947-1953$ \\
\hline
\end{tabular}

3 Republikanska komisija Tehnika i sport osnovana je 23. 6. 1946. u okviru Glavnoga odbora Fiskulturnog saveza Hrvatske te od 13. 7. 1948. djeluje kao zasebna organizacija na području tehničke kulture pod nazivom Narodna tehnika Hrvatske. 


\section{Četvrta veza}

Naziv/oznaka povezanoga entiteta

Vrsta veze

Opis veze

Nadnevci veze

Normirani oblik naziva

Ostali oblici naziva

\section{Povijest Fonda}

Prestankom aktivnosti stvaratelja, krajem šk. god. 1952./53., gradivo je preuzeo Gradski narodni odbor Pula, kao gradivo pasivnoga - likvidiranog stvaratelja. Gradivo je preuzeto fragmentarno, s obzirom da je dio gradiva po prestanku djelovanja stvaratelja prebačen u Željezničko-saobraćajnu školu u Zemunu gdje je i dio učenika nastavio školovanje.

\section{Način preuzimanja ili predaje}

Gradivo je preuzeto iz Narodnoga odbora Općine Pula u sklopu drugih fondova 16. siječnja 1961. po službenoj dužnosti. Temeljem Zapisnika o primopredaji arhivsko-registraturnog materijala likvidiranih poduzeća Općine Pula tadašnji Historijski arhiv u Pazinu preuzeo je registraturni materijal likvidiranih poduzeća, njih ukupno šest, te je gradivo predmetnoga fonda preuzeto kao jedno od njih. Prema navedenom zapisniku od 23. prosinca 1963. radilo se o nadopuni već ranije preuzetoga materijala likvidiranih poduzeća. Zapisnikom iz 1963. godine evidentirano je naknadno, dopunsko preuzimanje predmetnoga fonda, što se odnosilo na svih šest poduzeća, odnosno na njihovo gradivo. U svezi s količinom preuzetoga gradiva, prema dopisu upućenom od strane Općine Pula 7. listopada 1963. br. 09-9012/1-1963., za gradivo predmetnoga fonda navedeno je da se radi o količini »od 5 komada svežnjeva, sadržaja razne arhive približne težine $40 \mathrm{~kg}$ «. Navedenih se pet svežnjeva odnosi na dopunsko preuzimanje iz 1963. godine.

\section{SADRŽAJ I USTROJ FONDA}

\section{Sadržaj}

Gradivo Fonda sadrži spise u svezi s općim administrativnim poslovanjem, registraturnim pomagalima i povjerljivim spisima, u svezi sa stručnim poslovanjem samoga Tehnikuma te pedagošku dokumentaciju u svezi s različitim popisima i evidencijama učenika i njihove matične dosjee.

Unutar kadrovske su dokumentacije sadržani podatci o zaposlenim osobama, njihovu napredovanju tijekom službe, o polaganju stručnih ispita, promoviranju u viša zvanja, potom osobni dosjei zaposlenih i ostala dokumentacija koja svjedoči o kadrovskim poslovima. 
Financijsko poslovanje sadrži podatke o proračunu i završnom računu, podatke o isplatama plaća i drugim davanjima te evidentiranju uplata troškova učenika. Navedeni sadržaj ne oslikava u potpunosti cjelokupno gradivo nastalo djelatnošću stvaratelja jer je gradivo Fonda sačuvano fragmentarno.

\section{Odabiranje i izlučivanje}

Evidentirani podatci o eventualnim izlučivanjima kod stvaratelja ne postoje, a također nema podataka o eventualnim izlučivanjima u fazi pohrane gradiva kod sljednika, što također ne znači da ih nije bilo. Kako je u konačnici fragmentarno sačuvana mala količina gradiva Fonda, tijekom sređivanja nema izdvojenoga i predloženog gradiva za izlučivanje.

\section{Dopune}

S obzirom na način preuzimanja gradiva i na to da ne postoje saznanja o možebitnom postojanju dijela gradiva Fonda na terenu, u tom smislu se ne očekuju dopune Fonda. Eventualne su dopune, pak, moguće sređivanjem gradiva iste i slične provenijencije u DAPA-i, gdje bi se možda unutar gradiva drugih fondova mogli nalaziti i fragmenti gradiva ovoga fonda.

\section{Plan sređivanja}

Prije obrade gradiva obavljen je uvid u stanje Fonda te je uspoređen s postojećim popisom gradiva, koji se nije mogao smatrati obavijesnim pomagalom. Uvidom u stanje i sadržaj gradiva, prije samoga je sređivanja utvrđeno da je na određeni način bilo jednom popisano i najmanje dvaput tehnički opremljeno, odnosno pohranjeno u kutije, osim, naravno, onoga gradiva koje se zbog formata nije moglo u njih pohraniti. Zatečeni je popis gradiva u neku ruku bio i primopredajni popis, a iz njega samoga bilo je očito da je i on nastao na osnovu još nekoga i ranije izrađenoga priručnog popisa gradiva, moguće rađenoga tijekom samoga preuzimanja gradiva. S obzirom na sve navedeno, bilo je očito da je potrebno iznova utvrditi stanje i konkretan sadržaj gradiva te izraditi odgovarajuće obavijesno pomagalo, što je u konačnici i učinjeno.

Tijekom zadnjeg sređivanja gradivo fonda razdijeljeno je funkcionalno, sadržajno i prema vrsti dokumentacije, odnoseći se na pojedino područje djelatnosti, unutar kojeg je razvrstano na serije, te dalje na podserije, a unutar njih i na još niže jedinice pod-podserije. Sređeno je gradivo u potpunosti tehnički opremljeno. U samom su procesu sređivanja odstranjene korodirane metalne spojnice, izgužvani su spisi izravnani, a gradivo je uloženo u arhivske košuljice i pohranjeno u kutije. Na najnižim je razinama gradivo sređeno kronološki. U konačnici su formirane sljedeće serije $e^{4}$ :

1. RAD I POSLOVANJE

2. KADROVSKI POSLOVI

3. FINANCIJSKO POSLOVANJE.

4 Razdioba je gradiva na niže razine unutar pojedine serije vidljiva u dijelu »II. Arhivistički opisi i inventarni popisi nižih razina Fonda«. 


\section{DOSTUPNOST I KORIŠTENJE}

\section{Uvjeti dostupnosti i korištenja}

Fond ima status javnoga arhivskog gradiva, koje je dostupno sukladno Zakonu o arhivskom gradivu i arhivima ${ }^{5}$, Zakonu o zaštiti osobnih podataka ${ }^{6}$, Zakonu o pravu na pristup informacijama ${ }^{7}$ te Pravilniku o korištenju arhivskog gradiva ${ }^{8}$.

\section{Uvjeti objavljivanja ili umnožavanja}

Objavljivanje i umnožavanje dostupnoga gradiva moguće je sukladno navedenim $Z a$ konima i Pravilniku te Pravilniku o radu Čitaonice DAPA-e. Uvjeti umnožavanja arhivskoga gradiva u svrhu njegova objavljivanja utvrđuju se ugovorom između DAPA-e i korisnika gradiva.

\section{Jezik i pismo u gradivu}

Gradivo je Fonda pisano na hrvatskom i srpskom jeziku, latiničnim i ćiriličnim pismom, strojopisom i rukopisom.

\section{Tvarne značajke i tehnički uvjeti}

Većina je gradiva nastala na uredskom papiru. S obzirom na uvjete ranije pohrane, gradivo u manjoj mjeri sadrži mehanička oštećenja zbog načina pohrane i uporabe i kod stvaratelja i u kasnijim razdobljima skrbi. No, bez obzira na spomenuta manja oštećenja, ne predlaže se restauracija gradiva.

\section{Obavijesna pomagala}

Registraturna pomagala

1. Registraturna pomagala Uprave ŽT

2. Registraturna pomagala Škole ŽT

3. Registraturna pomagala Đačkog doma - Internata ŽT

4. Registraturna pomagala Željezničkog građevinskog tehnikuma Podbrdo

5. Kazala

\section{Arhivistička obavijesna pomagala}

1. HR-DAPA-257 Željeznički tehnikum Pula: arhivski popis. Zdenka Filiplić, DAPA, 1968.

\section{NN 46/17}

NN 106/12.

NN 85/15.

$8 \quad$ NN $67 / 99$. 
2. HR-DAPA-257 Željeznički tehnikum Pula: analitički inventar. Jasna Mrkonjić, DAPA, 2014.

\section{DOPUNSKI IZVORI}

\section{Postojanje i mjesto čuvanja izvornika}

Izvornici se čuvaju u DAPA-i, na adresi Istarskoga razvoda 2, Pazin.

\section{Postojanje i mjesto čuvanja preslika}

Ne postoje izrađene preslike fonda HR-DAPA-257 Željeznički tehnikum Pula.

\section{Dopunski izvori}

1. HR-DAPA-978 Školski komitet Komunističke partije Hrvatske Željeznički tehnikum Pula 1947-1953

2. HR-DAPA-114 Narodni odbor Grada Pule 1947-1955

3. HR-DAPA-390 Gradski komitet KPH/SKH Pula 1945-1955.

\section{KONTROLA OPISA}

\section{Identifikator ustanove i opisa}

HR DAPA ObP-257/AI-1

\section{Pravila ili propisi}

ISAD (G), Opća međunarodna norma za opis arhivskog gradiva, Zagreb, Hrvatski državni arhiv, 2001.

ISAAR (CPF), Međunarodna norma arhivističkog normiranog zapisa za pravne i fizičke osobe te obitelji, Zagreb, Hrvatski državni arhiv, 2006.

\section{Napomena arhivista}

1. Na razini opisa Fonda korišteni su razrađeniji elementi iz ISAAR(CPF), 5.2. Područje opisa umjesto elementa opisa Upravna povijest (ISAD $(G)$ 3.2.2.).

2. Na razini opisa Fonda elementi područja Kontrole opisa (ISAD(G)) zamijenjeni su razrađenijim oblikom iz ISAAR(CPF), 5.4. Područje kontrole.

3. Na mjestu upravne povijesti ili biografskih podataka iz $\operatorname{ISAD}(\mathrm{G})$-a iskorišten je element Opći kontekst iz ISAAR(CPF) radi razmatranja širega konteksta djelovanja stvaratelja. 
Izvori

Podatci o fondovima navedeni su u »Dopunskim izvorima«. Službena su glasila navedena kako u bilješkama, tako i u »Izvorima ovlasti«.

\title{
Status
}

Dovršen i dostupan opis.

\section{Nadnevak nastanka, izmjena i brisanja}

Konačna je verzija obavijesnoga pomagala izrađena 2014. godine.

\section{ARHIVISTIČKI OPISI I INVENTARNI POPISI NIŽIH RAZINA FONDA}

\author{
II/1. RAD I POSLOVANJE
}

Signatura
Naslov
Vrijeme nastanka gradiva
Razina opisa
Količina i nosač jedinice opisa
Sadržaj

Signatura

Razina opisa Sadrža

\author{
HR-DAPA-257/1 \\ Rad i poslovanje \\ 1947-1953 \\ Serija
}

2 knjige, 62 kutije, $6,50 \mathrm{~d} / \mathrm{m}^{9}$

Gradivo je serije obuhvaćeno unutar dvije podserije Opće administrativno poslovanje i Stručno poslovanje.

Prva podserija sadrži spise nastale općim administrativnim poslovanjem te u tom smislu sadrži različite spisovodstvene evidencije i prateće spise, od kojih je jedan dio označen materijalima povjerljive naravi. Gradivom su obuhvaćena registraturna pomagala (djelovodni protokoli) te kazala (indeksi) i spisi. Radi se o gradivu Uprave Željezničkoga tehnikuma (dalje ŽT), Škole ŽT-a, Đačkoga doma ŽT-a (Internata), potom gradivu Željezničkoga građevinskog tehnikuma Podbrdo te neidentificiranim registraturnim pomagalima.

Uz navedeno gradivo, unutar druge podserije obuhvaćeno je gradivo koje svjedoči o stručnom poslovanju stvaratelja u užem smislu pa tako sadrži materijale nastale radom upravnih i stručnih tijela ŽT-a, odnosno direktora i Pedagoškoga savjeta, te pedagošku dokumentaciju koja uključuje različite evidencije, indekse i imenike učenika, kao i njihove matične dosjee.

9 Premda serija obuhvaća 62 knjige, s obzirom na njihovu gotovo u potpunosti tehničku pohranu u kutije, u podatcima u svezi s količinom i nosačem zapisa na razini serije, kao knjige navedene su samo 2 koje su fizički ostale izvan kutija. 
II/1.1.

Signatura

Naslov

Vrijeme nastanka gradiva

Razina opisa

Količina i nosač zapisa

Sadržaj

Plan sređivanja

\section{HR-DAPA-257/1.1}

Opće administrativno poslovanje

1946-1953

Podserija

1 knjiga, 8 kutija, $0,85 \mathrm{~d} / \mathrm{m}^{10}$

Podserija obuhvaća dvije sadržajne cjeline: registraturna pomagala, odnosno različite djelovodne protokole $\mathrm{i}$ kazala/indekse, te povjerljive spise. Od registraturnih pomagala radi se o djelovodnim protokolima, indeksima i registrima. Unutar registraturnih pomagala nalaze se ona koja se odnose na rad Uprave ŽT-a, potom Škole ŽT-a te Đačkoga doma - Internata ŽT-a. Nakon njih slijede registraturna pomagala Željezničkoga građevinskog tehnikuma Podbrdo te ona neidentificirana. Registraturna su pomagala sačuvana gotovo u potpunosti, a od spisa samo oni označeni od stvaratelja stupnjem povjerljivosti. Ostali spisi nisu sačuvani.

Unutar podserije gradivo je razvrstano na niže razine te je sređeno kronološki.

Inventarni popis gradiva

\begin{tabular}{|c|c|c|c|c|}
\hline Signatura & Sadržaj/naslov gradiva & $\begin{array}{l}\text { Raspon } \\
\text { godina }\end{array}$ & $\begin{array}{l}\text { Teh. } \\
\text { jedinica }\end{array}$ & Napomena \\
\hline 1.1.1. & $\begin{array}{l}\text { Registraturna pomagala Uprave } \\
\text { Željezničkoga tehnikuma - povjerljiva } \\
\text { Urudžbeni zapisnici }\end{array}$ & & & \\
\hline 1.1.1./1 & $\begin{array}{l}\text { Djelovodni protokol za povjerljivu poštu } \\
\text { 1946., br. } 1 \text { - } 15 \text { (31. 8. - 31. 12.) } \\
\text { 1947., br. } 16-116 \text { (4. 1. - 27. 12.) } \\
\text { 1948., br. } 1-262(2.1 .-23.12 .)\end{array}$ & 1946-1948 & Kut. 1 & $\begin{array}{l}\text { Izvorna } \\
\text { numeracija } \\
2\end{array}$ \\
\hline \multirow[t]{2}{*}{ 1.1.1./2 } & Povjerljiv djelovodnik I. knjiga & 1950 & & 69 \\
\hline & $\begin{array}{l}\text { Registraturna pomagala Uprave } \\
\text { Željezničkoga tehnikuma }\end{array}$ & & & \\
\hline 1.1.1./3 & $\begin{array}{l}\text { Djelovodni protokol za 1946. - } 1947 . \\
\text { 1946., br. } 1-1305 \text { (2. 9. - 31.12.) } \\
\text { 1947., br. } 1306-1981 \text { (3. 1. - 9. 4.) }\end{array}$ & $1946-1947$ & & 1 \\
\hline 1.1.1./4 & $\begin{array}{l}\text { Djelovodni protokol jedinice II } \\
\text { br. 1981-4874 (9. 4. - 20. 11.) }\end{array}$ & 1947 & & 3 \\
\hline 1.1.1./5 & $\begin{array}{l}\text { Djelovodni protokol jedinice III } \\
\text { br. } 4871-5255 \text { (14. 9. }-25.10 .)\end{array}$ & 1947 & & 4 \\
\hline 1.1.1./6 & $\begin{array}{l}\text { Djelovodni protokol jedinice IV } \\
\text { 1947., br. } 1-1267 \text { (18. 10. 1947. }-24.1 . \\
\text { 1948.) } \\
\text { 1948., br. } 1268-2020\end{array}$ & $1947-1948$ & Kut. 2 & 5 \\
\hline
\end{tabular}

10 Knjige podserije fizički su pohranjene u kutije, izvan kutije ostala je samo jedna, koja je kao takva zasebno u podatcima o količini iskazana. 
J. MRKONJIĆ, Sumarno-analitički inventar fonda Željeznički tehnikum Pula 1947. - 1953. / VIA svezak 24

\begin{tabular}{|c|c|c|c|c|}
\hline 1.1.1./7 & $\begin{array}{l}\text { Djelovodni protokol jedinice } \mathrm{V} \\
\text { br. } 2021-4010(24.1 .-9.4 .)\end{array}$ & 1948 & & 6 \\
\hline 1.1.1./8 & $\begin{array}{l}\text { Djelovodni protokol } \\
\text { br. 4011- } 6870(9.4 .-13.7 .)\end{array}$ & 1948 & & 7 \\
\hline 1.1.1./9 & $\begin{array}{l}\text { Djelovodni protokol } \\
\text { br. } 6871-8860(13.7 .-16.9 .)\end{array}$ & 1948 & & 8 \\
\hline 1.1.1./10 & $\begin{array}{l}\text { Djelovodni protokol } \\
\text { br. } 8861-10860(16.9 .-15.11 .)\end{array}$ & 1948 & Kut. 3 & 9 \\
\hline 1.1.1./11 & \begin{tabular}{|l} 
Djelovodni protokol \\
br. $10861-12777$ (9. 11. - 31. 12.)
\end{tabular} & 1948 & & 10 \\
\hline 1.1.1./12 & \begin{tabular}{|l} 
Djelovodni protokol \\
br. $9281 / 1-9281 / 681$ (28. 9. - 4. 10.)
\end{tabular} & 1948 & & 11 \\
\hline 1.1.1./13 & $\begin{array}{l}\text { Djelovodni protokol } \\
\text { br. } 1-1990(3.1 .-28.2 .)\end{array}$ & 1949 & & 15 \\
\hline 1.1.1./14 & $\begin{array}{l}\text { Djelovodni protokol } \\
\text { br. } 2001-4450 \text { (28. 2. - 10. 10.) }\end{array}$ & 1949 & Kut. 4 & 13 \\
\hline 1.1.1./15 & $\begin{array}{l}\text { Djelovodni protokol } \\
\text { 1949., br. } 4451-5096 \text { (10. 10. - 31. 12.) } \\
\text { 1950., br. } 1-1990 \text { (1. 1. - 19. 12.) }\end{array}$ & $1949-1950$ & & 14 \\
\hline 1.1.1./16 & $\begin{array}{l}\text { Djelovodni protokol } \\
\text { 1950., br. } 2927-3276 \text { (21. 11. - 31. 12.) } \\
\text { 1951., br. } 1-39 \text { (2. 1. - 9. 1.) }\end{array}$ & $1950-1951$ & & 18 \\
\hline 1.1.1./17 & $\begin{array}{l}\text { Djelovodni protokol } \\
\text { br. } 40-1580(9.1 .-21.7 .)\end{array}$ & 1951 & & 21 \\
\hline 1.1.1./18 & $\begin{array}{l}\text { Djelovodni protokol } \\
\text { 1951., br. } 1581-2574 \text { (21. 7. - 29. 12.) } \\
\text { 1952., br. } 1-840 \text { (3. 1. - 20. 6.) }\end{array}$ & $1951-1952$ & Kut. 5 & 23 \\
\hline 1.1.1./19 & $\begin{array}{l}\text { Djelovodni protokol } \\
\text { br. } 841-1804(14.6 .-30.12 .)\end{array}$ & 1952 & & 24 \\
\hline 1.1.1./20 & $\begin{array}{l}\text { Djelovodni protokol } \\
\text { br. } 1-961(5.1 .-23.8 .)\end{array}$ & 1953 & & 25 \\
\hline & Registraturna pomagala - Škola ŽT-a & & & \\
\hline 1.1.1./21 & $\begin{array}{l}\text { Djelovodni protokol I } \\
\text { 1949., br. } 1-331 \text { (9. 10. - 31. 12.) } \\
\text { 1950., br. } 1-2000(3.1 .-25.8 .)\end{array}$ & $1949-1950$ & & 12 \\
\hline 1.1.1./22 & $\begin{array}{l}\text { Djelovodni protokol II/1950 } \\
\text { br. } 2001-2391(26.8 .-20.9 .)\end{array}$ & 1950 & Kut. 6 & 19 \\
\hline \multirow[t]{2}{*}{ 1.1.1./23 } & $\begin{array}{l}\text { Djelovodni protokol III/1950 } \\
\text { br. } 2392-2929(21.9 .-24.11 .)\end{array}$ & & & 20 \\
\hline & $\begin{array}{l}\text { Registraturna pomagala - Đačkoga doma - } \\
\text { Internata ŽT-a }\end{array}$ & & & \\
\hline 1.1.1./24 & $\begin{array}{l}\text { Djelovodni protokol povjerljive pošte } \\
\text { 1949., br. } 1-309(6.1 .-31.12 .) \\
\text { 1950., br. } 1-335(2.1 .-26.12 .) \\
\text { 1951., br. } 1-85(2.1 .-11.12 .) \\
\text { 1952., br. } 1-14(21.2 .-4.12 .) \\
\text { 1953., br. } 1-7(23.2 .-17.4 .) \\
\end{array}$ & $1949-1953$ & & 30 \\
\hline
\end{tabular}




\begin{tabular}{|c|c|c|c|c|}
\hline $1.1 .1 . / 25$ & $\begin{array}{l}\text { Djelovodni protokol } \\
\text { 1950., } 1991-2571(20.9 .-30.12 .) \\
\text { 1951., } 1-1290(2.1 .-19.12 .)\end{array}$ & $1950-1951$ & & 16 \\
\hline \multirow[t]{2}{*}{ 1.1.1./26 } & $\begin{array}{l}\text { Djelovodni protokol } \\
\text { 1951., br. } 1291-1320 \text { (19. 12. - 28. 12.) } \\
\text { 1952., br. } 1-1384 \text { (3. 1. - 20. 6.) }\end{array}$ & 1951-1952 & & 22 \\
\hline & $\begin{array}{l}\text { Registraturna pomagala Željezničkoga } \\
\text { građevinskog tehnikuma Podbrdo }\end{array}$ & & Kut. 7 & \\
\hline 1.1.1./27 & $\begin{array}{l}\text { Djelovodni protokol - povjerljivo } \\
\text { 1949., br. } 1-6(18.6 .-4.11 .) \\
\text { 1950., br. } 1-6(10.1 .-2.11 .) \\
\text { 1951., br. } 1 \text { - } 18(27.1 .-28.9 .)\end{array}$ & 1949-1951 & & 63 \\
\hline \multirow[t]{2}{*}{ 1.1.1./28 } & $\begin{array}{l}\text { Djelovodni protokol } \\
\text { 1950., br. } 1 \text { - } 1127 \text { (3. 1. - 28. 12.) } \\
\text { 1951., br. } 1 \text { - } 850 \text { (2. 1. - 16. 8.) }\end{array}$ & $1950-1951$ & & 17 \\
\hline & Kazala/Indeksi & & & \\
\hline 1.1.1./29 & Indeks akata & 1950 & & 26 \\
\hline 1.1.1./30 & Indeks po predmetima & 1952 & & 27 \\
\hline \multirow[t]{2}{*}{ 1.1.1./31 } & Indeks po predmetima & $1951-1953$ & & 28 \\
\hline & Neidentificirana registraturna pomagala & & & \\
\hline $1.1 .1 . / 32$ & Djelovodni protokol & $1951-1953$ & & $\begin{array}{l}\text { (Fragmentarno } \\
\text { bez korica) }\end{array}$ \\
\hline 1.1.1./33 & $\begin{array}{l}\text { Djelovodni protokol } \\
\text { Djelovodni protokol (Odbor za fizički } \\
\text { odgoj) } \\
\text { br. } 1-51 \text { (20.1. - 14. 9.) }\end{array}$ & 1953 & & \\
\hline 1.1.1./34 & Registar (predmetni) & 1952 & $\begin{array}{l}\text { Izvan } \\
\text { kutije }\end{array}$ & 29 \\
\hline 1.1.2. & Povjerljivi spisi & $1946-1951$ & kut. 8 & \\
\hline
\end{tabular}

\section{$\mathrm{II} / 1.2$.}

Signatura
Naslov
Vrijeme nastanka gradiva
Razina opisa
Količina i nosač zapisa
Sadržaj

HR-DAPA-257/1.2

Stručno poslovanje

1945-1946] 1947-1953

Podserija

1 knjiga, 55 kutija, $5,60 \mathrm{~d} / \mathrm{m}^{11}$

Gradivom podserije grupirana su dva područja poslovanja, od kojih se prvo odnosi na planiranje, informiranje te postavljanja radnih zadataka i praćenja njihova izvršenja. Navedeno obuhvaća izvješća i gradivo nastalo radom upravnih i stručnih tijela (Pedagoškoga savjeta i direktora Škole). Druga cjelina gradiva uključuje pedagošku dokumentaciju, s učeničkim evidencijama i popisima te njihovim matičnim dosjeima.

11 Knjige podserije fizički su pohranjene u kutije, izvan kutije ostala je samo jedna, koja je kao takva u podatcima o količini zasebno iskazana. 
Plan sređivanja

Inventarni popis gradiva

\begin{tabular}{|c|c|c|c|c|}
\hline Signatura & Sadržaj/naslov gradiva & $\begin{array}{l}\text { Raspon } \\
\text { godina }\end{array}$ & $\begin{array}{l}\text { Teh. } \\
\text { jedinica }\end{array}$ & Napomena \\
\hline 1.2.1. & Izvješća & & Kut. 8/a & \\
\hline 1.2.1.1. & $\begin{array}{l}\text { Izvještaji o situaciji adaptacijskih radova } \\
\text { u ŽT-u Pula. } \\
\text { (Uz navedeno i Ugovor između VP br. } \\
34279 \text { p. Pula i ŽT-a o primopredaji bivše } \\
\text { kasarne Principe Piemonte na privremenu } \\
\text { upotrebu 28. 3. 1949.) }\end{array}$ & 1949 & & \\
\hline 1.2.1.2. & $\begin{array}{l}\text { Statistička izvješća/pregledi o } \\
\text { postignutom uspjehu učenika škole }\end{array}$ & $1951-1953$ & & \\
\hline 1.2.1.3. & $\begin{array}{l}\text { Izvješća o radu nastavnoga osoblja i } \\
\text { stručnom kadru }\end{array}$ & $1951 / 1953$ & & \\
\hline 1.2.2. & Upravna i stručna tijela & & & \\
\hline 1.2.2.1. & Direktor Škole & & & \\
\hline 1.2.2.1.1. & $\begin{array}{l}\text { Oglasi i naredbe direktora Škole (Knjiga } \\
\text { objava, naredaba i saopštenja) }\end{array}$ & 1948-1949 & & 59 \\
\hline 1.2.2.1.2. & $\begin{array}{l}\text { Knjiga naredaba (za osoblje) } \\
\text { 25. 1. 1951. - 16. 4. } 1953 .\end{array}$ & $1951-1953$ & & 62 \\
\hline 1.2.2.1.3. & $\begin{array}{l}\text { Knjiga naredaba za osoblje nastavno i } \\
\text { administrativno (Glavna za službenike i } \\
\text { radnike 16. 8. 1950. - 20. 5. 1953.) }\end{array}$ & $1950-1953$ & kut. 9 & 60 \\
\hline 1.2.2.1.4. & $\begin{array}{l}\text { Naredbe za učenike svih odsjeka šk. g. } \\
\text { 50./51. i 1951./52. te } 1952 . / 53 \text {. } \\
(16.8 .1950 .-27.5 .1953 .)\end{array}$ & $1950-1953$ & & 61 \\
\hline 1.2.2.2. & Pedagoški savjet & & & \\
\hline & Zapisnici sjednica PS (21. 3. - 19. 6.) & 1950 & & 56 \\
\hline & Isto (25. 8. 1950. - 14. 5. 1952.) & $1950-1952$ & & 58 \\
\hline 1.2.3. & Pedagoška dokumentacija & & & \\
\hline 1.2.3.1. & Evidencije učenika & & & \\
\hline 1.2.3.1./1 & $\begin{array}{l}\text { Evidencija učenika šk. g. 1949./50. i } \\
\text { 1950./1951. sa stanjem od 1. 1. 1950. }\end{array}$ & $1949-1950$ & & 39 \\
\hline $1.2 .3 .1 . / 2$ & $\begin{array}{l}\text { Alfabetski spisak učenika po odsecima, } \\
\text { razredima i odelenjima za šk. g. 50./51. }\end{array}$ & $1950-1951$ & & 40 \\
\hline 1.2.3.1./3 & Učenici pod bolovanjem i isključeni & 1952 & & \\
\hline 1.2.3.2. & Indeksi učenika & & Kut. 10 & \\
\hline 1.2.3.2./1 & Spisak đaka ŽT - Indeks & 1947 & & 31 \\
\hline 1.2.3.2./2 & Indeks učenika & 1947-1949 & & 32 \\
\hline 1.2.3.2./3 & Indeks učenika & $1949-1950$ & & 34 \\
\hline 1.2.3.2./4 & Indeks imena (učenika) & $1949-1950$ & & 35 \\
\hline 1.2.3.2./5 & Indeks učenika & 1949-1951 & & 36 \\
\hline 1.2.3.2./6 & Indeks učenika & $1951-1952$ & & 38 \\
\hline
\end{tabular}

Gradivo je podijeljeno na niže razine unutar podserije te je sređeno kronološki. 


\begin{tabular}{|c|c|c|c|c|}
\hline $1.2 .3 .2 . / 7$ & Indeks učenika & 1951 & Izvan kutije & 41 \\
\hline $1.2 .3 .2 . / 8$ & Indeks po imenima & 1951-1953 & Kut. 11 & 42 \\
\hline 1.2 .3 .3 & Imenici učenika & & & \\
\hline 1.2.3.3./1 & Imenik učenika ŽT-a Pula & 1949 & & 33 \\
\hline $1.2 .3 .3 . / 2$ & Imenik učenika & $1950-1951$ & & 37 \\
\hline $1.2 .3 .3 . / 3$ & Imenik učenika & 1951-1953 & & 43 \\
\hline $1.2 .3 .3 . / 4$ & Imenik učenika & 1953 & & 44 \\
\hline \multirow[t]{37}{*}{1.2 .4}$. & Matični dosjei učenika & $1947-1953$ & & \\
\hline & $1-23$ & & Kut. 12 & \\
\hline & $24-42$ & & Kut. 13 & \\
\hline & $43-65$ & & Kut. 14 & \\
\hline & $66-88$ & & Kut. 15 & \\
\hline & $89-107$ & & Kut. 16 & \\
\hline & $108-131$ & & Kut. 17 & \\
\hline & $132-156$ & & Kut. 18 & \\
\hline & $157-177$ & & Kut. 19 & \\
\hline & $178-221$ & & Kut. 20 & \\
\hline & $222-265$ & & Kut. 21 & \\
\hline & $266-312$ & & Kut. 22 & \\
\hline & $313-357$ & & Kut. 23 & \\
\hline & $358-405$ & & Kut. 24 & \\
\hline & $406-451$ & & Kut. 25 & \\
\hline & $452-495$ & & Kut. 26 & \\
\hline & $496-536$ & & Kut. 27 & \\
\hline & $537-586$ & & Kut. 28 & \\
\hline & $587-635$ & & Kut. 29 & \\
\hline & $636-681$ & & Kut. 30 & \\
\hline & $682-727$ & & Kut. 31 & \\
\hline & $728-772$ & & Kut. 32 & \\
\hline & $773-814$ & & Kut. 33 & \\
\hline & $815-860$ & & Kut. 34 & \\
\hline & $861-900$ & & Kut. 35 & \\
\hline & $901-944$ & & Kut. 36 & \\
\hline & $945-990$ & & Kut. 37 & \\
\hline & $991-1033$ & & Kut. 38 & \\
\hline & $1034-1080$ & & Kut. 39 & \\
\hline & $1081-1128$ & & Kut. 40 & \\
\hline & $1129-1177$ & & Kut. 41 & \\
\hline & $1178-1223$ & & Kut. 42 & \\
\hline & $1124-1274$ & & Kut. 43 & \\
\hline & $1275-1321$ & & Kut. 44 & \\
\hline & $1322-1361$ & & Kut. 45 & \\
\hline & $1362-1408$ & & Kut. 46 & \\
\hline & $1409-1455$ & & Kut. 47 & \\
\hline
\end{tabular}




\begin{tabular}{|l|l|l|l|l|}
\hline & $1456-1507$ & & Kut. 48 & \\
\hline & $1508-1555$ & & Kut. 49 & \\
\hline & $1556-1600$ & & Kut. 50 & \\
\hline & $1601-1651$ & & Kut. 51 & \\
\hline & $1652-1693$ & Kut. 52 & \\
\hline & $1694-1736$ & & Kut. 53 & \\
\hline & $1737-1781$ & & Kut. 54 & \\
\hline & $1782-1829$ & & Kut. 55 & \\
\hline & $1830-1875$ & & Kut. 56 & \\
\hline & $1876-1920$ & & Kut. 57 & \\
\hline & $1921-1967$ & & Kut. 58 & \\
\hline & $1968-2011$ & Kut. 59 & \\
\hline & $2012-2061$ & Kut. 60 & \\
\hline & $2062-2113$ & Kut. 61 & \\
\hline 1.2 .5$. & $2114-2140$ & & Kut. 62 & \\
\hline & Učenička praksa & & & \\
\hline 1.2 .6$. & $\begin{array}{l}\text { Izvještaji s učeničke prakse obavljene u } \\
\text { žljezničko-saobraćajnim školama }\end{array}$ & 1946 & & \\
\hline 1.2 .6 .1$. & Pozivi/obavijesti učenicima & & & \\
\hline 1.2 .6 .2$. & Obavijesti učenicima o prijamu u školu & 1947 & & \\
\hline & $\begin{array}{l}\text { Obavijesti o vraćenim osobnim } \\
\text { dokumentima učenika }\end{array}$ & $1948-1949$ & & \\
\hline
\end{tabular}

\section{II/2. KADROVSKI POSLOVI}

\section{Signatura \\ Naslov \\ Vrijeme nastanka gradiva \\ Razina opisa \\ Količina i nosač jedinice opisa Sadržaj}

HR-DAPA-257/2

Kadrovski poslovi

1947-1953

Serija

6 knjiga, $12+1 / 4$ kutije, $1,10 \mathrm{~d} / \mathrm{m}$

Gradivo serije sadrži evidencije zaposlenih, prvenstveno matične knjige, potom ostale evidencije zaposlenih (nastavnoga, odnosno stručnoga kadra, službenika i radnika). Serija također sadrži posebno izdvojene ugovore o radu te različite ocjene nastavnoga osoblja i stručnoga kadra koji je izravno sudjelovao u nastavnom procesu. $U$ svezi sa stručnim usavršavanjem i napredovanjem, gradivo se odnosi na polaganje propisanih obvezatnih stručnih ispita te također sadrži prijedloge za unaprjeđenja u viša zvanja temeljem položenih ispita i napredovanja. 


\section{Plan sređivanja}

Signatura

Naslov

Vrijeme nastanka gradiva

Razina opisa

Količina i nosač zapisa

Sadržaj

Plan sređivanja
Serija je podijeljena na sedam podserija, od kojih je unutar svake gradivo dalje razvrstano na niže jedinice.

2.1. Matične knjige zaposlenih

2.2. Ostale evidencije zaposlenih

2.3. Ugovori o radu

2.4. Obavijesti, rješenja, potvrde

2.5. Ocjene nastavnoga osoblja i stručnoga kadra

2.6. Stručno usavršavanje i napredovanje tijekom službovanja

2.7. Osobni dosjei zaposlenih

$\mathrm{II} / 2.1$.
HR-DAPA-257/2.1

Matične knjige zaposlenih

1950-1953

Podserija

5 knjiga, $0,07 \mathrm{~d} / \mathrm{m}$

Podserija sadrži matične knjige zaposlenih, nastavnoga i stručnoga kadra te službenika i radnika ŽT-a.

Gradivo je podijeljeno na niže razine unutar podserije, unutar kojih je složeno kronološki.

Inventarni popis gradiva

\begin{tabular}{|l|l|l|l|l|}
\hline Signatura & Sadržaj/naslov gradiva & Raspon godina & Teh. jedinica & Napomena \\
\hline 2.1.1. & Matična knjiga službenika & 1950 & $\begin{array}{l}\text { S obzirom na format } \\
\text { gradiva, nije ga bilo } \\
\text { moguće pohraniti u } \\
\text { kutije. } \\
63 \text { (izv. num.) }\end{array}$ \\
\hline & Matična knjiga službenika & $1950-1953$ & & 65 \\
\hline 2.1.2. & Matična knjiga radnika & 1950 & 66 \\
\hline & Matična knjiga radnika & $1950-1953$ & & 67 \\
\hline 2.1.3. & $\begin{array}{l}\text { Matična knjiga nastavnika } \\
\text { Uprave Škole }\end{array}$ & $1951-1953$ & & 68 \\
\hline
\end{tabular}

$\mathrm{II} / 2.2$.

Signatura

Naslov

Vrijeme nastanka gradiva

Razina opisa

Količina i nosač zapisa
HR-DAPA-257/2.2

Ostale evidencije zaposlenih

1947-1953

Podserija

1 knjiga, 2+1/4 kutije, $0,14 \mathrm{~d} / \mathrm{m}$ 
Sadržaj

Plan sređivanja
Podserija sadrži evidencije zaposlenih, odnosno one evidencije koje ne pripadaju matičnim knjigama, a što uključuje statuse zaposlenih, potom različite druge evidencije, poput one promjene osoblja, evidencije po alfabetskom redu, evidencije kursista različitih jedinica.

Gradivo je podijeljeno na niže razine unutar podserije, unutar kojih je složeno kronološki.

Inventarni popis gradiva

\begin{tabular}{|c|c|c|c|c|}
\hline Signatura & Sadržaj/naslov gradiva & Raspon godina & Teh. jedinica & Napomena \\
\hline 2.2.1. & $\begin{array}{l}\text { Status radnika ŽT-a Pula započet } 29 . \\
\text { 10. 1947. (službenici i radnici) }\end{array}$ & 1947 & Kut. 63 & 47 (izv. num.) \\
\hline & Status osoblja ŽT-a Pula & 1947 & & \\
\hline & Status radnika ŽT-a Pula & 1952 & & 50 \\
\hline & Status (radnika) & $1952-1953$ & & 51 \\
\hline & Status službenika ŽT-a Pula & $1945-1948$ & & Izvan kutije \\
\hline & Status delavca ŽGT-a Podbrdo & 1950-1951 & & 49 \\
\hline 2.2 .2 . & Knjiga promjene osoblja započeta 1947. & 1947 & & 52 \\
\hline 2.2 .3 . & $\begin{array}{l}\text { Evidencija službenika po alfabetskom } \\
\text { redu }\end{array}$ & & Kut. 64 & 54 \\
\hline 2.2.4. & $\begin{array}{l}\text { Popis promjene osoblja pri Upravi ŽT-a } \\
\text { Pula (započeto 31. 3. 1950.) }\end{array}$ & & & 55 \\
\hline 2.2.5. & Knjiga evidencije kursista & 1950 & & 53 \\
\hline
\end{tabular}

$\mathrm{II} / 2.3$.

Signatura

Naslov

Vrijeme nastanka gradiva

Razina opisa

Količina i nosač zapisa

Sadržaj

Plan sređivanja
HR-DAPA-257/2.3

Ugovori o radu

1949

Podserija

1 košuljica, $0,01 \mathrm{~d} / \mathrm{m}$

Podserija sadrži ugovore o radu talijanskih državljana, sklopljene na određeno vrijeme.

Gradivo je složeno kronološki.

Inventarni popis gradiva

\begin{tabular}{|l|l|l|l|l|}
\hline Signatura & Sadržaj/naslov gradiva & Raspon godina & Teh. jedinica & Napomena \\
\hline 2.3. & $\begin{array}{l}\text { Ugovori o radu talijanskih državljana na } \\
\text { određeno vrijeme }\end{array}$ & 1949 & Kut. 64 & \\
\hline
\end{tabular}


$\mathrm{II} / 2.4$.

Signatura

Naslov

Vrijeme nastanka gradiva

Razina opisa

Količina i nosač zapisa

Sadržaj

Plan sređivanja
HR-DAPA-257/2.4

Obavijesti, rješenja, potvrde

1949/1952

Podserija

1 košuljica, $0,01 \mathrm{~d} / \mathrm{m}$

Podserija sadrži obavijesti i informacije te podatke u svezi s ostvarivanjem materijalnih prava zaposlenih.

Gradivo je složeno kronološki.

Inventarni popis gradiva

\begin{tabular}{|l|l|l|l|l|}
\hline Signatura & Sadržaj/naslov gradiva & Raspon godina & Teh. jedinica & Napomena \\
\hline 2.4. & Obavijesti, rješenja, potvrde & $1950-1952$ & Kut. 64 & \\
\hline
\end{tabular}

$\mathrm{II} / 2.5$.

Signatura

Naslov

Vrijeme nastanka gradiva

Razina opisa

Količina i nosač zapisa

Sadržaj

Plan sređivanja

Inventarni popis gradiva

\begin{tabular}{|l|l|l|l|l|}
\hline Signatura & Sadržaj/naslov gradiva & Raspon godina & Teh. jedinica & Napomena \\
\hline 2.5.1. & Ocjene nastavnoga osoblja šk. god. & $1948 / 1952$ & Kut. 64 & \\
\hline 2.5.2. & $\begin{array}{l}\text { Ocjene i biografije službenika i majstora } \\
\text { premještenih iz ŽT-a u druge ustanove }\end{array}$ & 1952 & & \\
\hline 2.5.3. & $\begin{array}{l}\text { Ocjene i biografije radnika koji nisu } \\
\text { obuhvaćeni statusom }\end{array}$ & 1948 & & \\
\hline
\end{tabular}

II/2.6.
HR-DAPA-257/2.5

Ocjene nastavnoga osoblja i stručnoga kadra

1948/1952

Podserija

1 košuljica, $0,05 \mathrm{~d} / \mathrm{m}$

Podserija sadrži ocjene i biografije radnika koji nisu obuhvaćeni prethodnim evidencijama, odnosno matičnim knjigama ili statusima.

Gradivo je podijeljeno na niže razine unutar podserije, unutar kojih je složeno kronološki.

\section{Signatura \\ Naslov \\ Vrijeme nastanka gradiva \\ Razina opisa}

HR-DAPA-257/2.6

Stručno usavršavanje i kretanje kroz službu

1947. 1951-1952

Podserija 
Količina i nosač zapisa Sadržaj

Plan sređivanja
1 košuljica, $0,10 \mathrm{~d} / \mathrm{m}$

Podserijom je obuhvaćeno gradivo koje evidentira stručno usavršavanje, odnosno polaganje stručnih ispita i temeljem toga napredovanje tijekom službovanja te stegovne mjere $\mathrm{i}$ postupke.

Gradivo je podijeljeno na niže razine unutar podserije, unutar kojih je složeno kronološki.

Inventarni popis gradiva

\begin{tabular}{|c|c|c|c|c|}
\hline Signatura & Sadržaj/naslov gradiva & Raspon godina & Teh. jedinica & Napomena \\
\hline \multirow[t]{2}{*}{ 2.6.1. } & Stručni ispiti & 1951 & Kut. 65 & \\
\hline & $\begin{array}{l}\text { Popis službenika koji su dužni polagati } \\
\text { stručni ispit } 1951 .\end{array}$ & & & \\
\hline 2.6 .2$. & Nastavno osoblje & & & \\
\hline 2.6.2.1. & $\begin{array}{l}\text { Prijedlozi za napredovanje službenika u } \\
\text { viša zvanja }\end{array}$ & 1952 & & \\
\hline 2.6.2.2. & $\begin{array}{l}\text { Osobni popisni listovi stalnoga nastav- } \\
\text { nog osoblja }\end{array}$ & 1952 & & \\
\hline 2.6.2.3. & $\begin{array}{l}\text { Zbirni pregledi i rješenja o promicanju } \\
\text { radnika Tehnikuma u stručna zvanja }\end{array}$ & 1951 & & \\
\hline \multirow[t]{2}{*}{2.6 .3 . } & Stegovne mjere i postupci & 1947-1952 & & \\
\hline & $\begin{array}{l}\text { Očevidnik kažnjenih službenika i } \\
\text { radnika koji su neopravdano izostali iz } \\
\text { službe }\end{array}$ & & & \\
\hline
\end{tabular}

$\mathrm{II} / 2.7$.

Signatura

Naslov

Vrijeme nastanka gradiva

Razina opisa

Količina i nosač zapisa

Sadržaj
HR-DAPA-257/2.7

Osobni dosjei zaposlenih

1947-1953

Podserija

10 kutija, $1,00 \mathrm{~d} / \mathrm{m}$

Gradivo uključuje personalne dosjee zaposlenoga osoblja: nastavnika, instruktora, odnosno stručnoga kadra, potom administrativnoga te pomoćnog i tehničkog osoblja. Nastavno je osoblje obuhvatilo zaposlene koji su izravno bili uključeni u održavanje nastavnoga procesa u teorijskom i praktičnom radu.

Pomoćno tehničko osoblje bilo je angažirano na ostalim poslovima u svezi s nabavkom svega što je bilo potrebno za normalno funkcioniranje poslovnih i ostalih aktivnosti (održavanje higijene, kuhanje, spremanje, popravke i slični poslovi). 
Plan sređivanja

Inventarni popis gradiva

\begin{tabular}{|l|l|l|l|l|}
\hline Signatura & Sadržaj/naslov gradiva & Raspon godina & Teh. jedinica & Napomena \\
\hline 2.7. & Osobni dosjei zaposlenih & $1947-1953$ & & \\
\hline & $1-30$ & & Kut. 66 & \\
\hline & $31-65$ & & Kut. 67 & \\
\hline & $66-106$ & & Kut. 68 & \\
\hline & $107-119$ & & Kut. 69 & \\
\hline & $120-136$ & & Kut. 70 & \\
\hline & $137-180$ & & Kut. 71 & \\
\hline & $181-214$ & & Kut. 72 & \\
\hline & $215-258$ & & Kut. 73 & \\
\hline & $259-300$ & & Kut. 74 & \\
\hline & $301-306$ & Kut. 75 & \\
\hline
\end{tabular}

\section{II/3. FINANCIJSKO POSLOVANJE}

\section{Signatura}

Naslov

Vrijeme nastanka gradiva

Razina opisa

Količina i nosač jedinice opisa

Sadržaj

\section{Plan sređivanja}

Gradivo je složeno po rednom broju personalnih dosjea s odgovarajućim dodijeljenim signaturama koje se poklapaju s brojem dosjea jer su dosjei numerirani prilikom sređivanja te se svaki pojedinačni broj dosjea odnosi na samo jednu osobu.

T/3. FINANCIJSKO POSLOVANJE 
Vrijeme nastanka gradiva

Razina opisa

Količina i nosač zapisa

Sadržaj

Plan sređivanja
1951

Podserija

1 košuljica, $0,02 \mathrm{~d} / \mathrm{m}$

Gradivo sadrži podatke o proračunu ŽT-a za 1951. i popratnu dokumentaciju u svezi s njegovim odobrenjem i usvajanjem.

Gradivo je složeno kronološki.

Inventarni popis gradiva podserije

\begin{tabular}{|l|l|l|l|l|}
\hline Signatura & Sadržaj/naslov gradiva & $\begin{array}{l}\text { Raspon go- } \\
\text { dina }\end{array}$ & Teh. jedinica & Napomena \\
\hline 3.1. & $\begin{array}{l}\text { Godišnji budžet ŽT za 1951. god. i po- } \\
\text { pratna dokumentacija }\end{array}$ & 1951 & Kut. 75 & \\
\hline
\end{tabular}

$\mathrm{II} / 3.2$.

Signatura

Naslov

Vrijeme nastanka gradiva

Razina opisa

Količina i nosač zapisa

Sadržaj

Plan sređivanja
HR-DAPA-257/3.2

Završni račun

1952

Podserija

1 košuljica, 0,01

Gradivo sadrži podatke o završnom računu ŽT-a za

1951. g. i popratnu dokumentaciju.

Gradivo je složeno kronološki.

Inventarni popis gradiva

\begin{tabular}{|l|l|l|l|l|}
\hline Signatura & Sadržaj/naslov gradiva & Raspon godina & Teh. jedinica & Napomena \\
\hline 3.2. & Završni račun ŽT-a za 1951. & 1952 & Kut. 75 & \\
\hline
\end{tabular}

\section{$\mathrm{II} / 3.3$}

Signatura

Naslov

Vrijeme nastanka gradiva

Razina opisa

Količina i nosač zapisa

Sadržaj

Plan sređivanja
HR-DAPA-257/3.3

Podaci o osnovnim sredstvima

1949/1953

Podserija

1 košuljica, 0,02

Gradivo sadrži podatke o inventarnim popisima osnovnih sredstava za rad i različitih robnih zaliha.

Gradivo je složeno kronološki. 
Inventarni popis gradiva

\begin{tabular}{|l|l|l|l|l|}
\hline Signatura & Sadržaj/naslov gradiva & Raspon godina & Teh. jedinica & Napomena \\
\hline 3.3. & $\begin{array}{l}\text { Podaci o osnovnim sredstvima (popisi } \\
\text { inventara) }\end{array}$ & $1949 / 1953$ & Kut. 75 & \\
\hline
\end{tabular}

$\mathrm{II} / 3.4$.

\section{Signatura \\ Naslov \\ Vrijeme nastanka gradiva \\ Razina opisa \\ Količina i nosač zapisa \\ Sadržaj}

Plan sređivanja

Inventarni popis gradiva

\begin{tabular}{|l|l|l|l|l|}
\hline Signatura & Sadržaj/naslov gradiva & Raspon godina & Teh. jedinica & Napomena \\
\hline \multirow{3}{*}{3.4.} & Evidencija uplata troškova Internata & $1951-1952$ & Kut. 76 & \\
\cline { 2 - 5 } & Isto & $1952-1953$ & Kut. 77-78 & \\
\hline
\end{tabular}

HR-DAPA-257/3.4

Evidencije troškova uplata Internata

1951-1953

Podserija

3 kutije, $0,30 \mathrm{~d} / \mathrm{m}$

Gradivo sadrži podatke o evidencijama uplata financijskih obveza/potraživanja Internata prema učenicima - korisnicima usluga smještaja i prehrane pri internatu ŽT-a.

Gradivo je složeno kronološki.

\section{$\mathrm{II} / 3.5$.}

\section{Signatura \\ Naslov \\ Vrijeme nastanka gradiva \\ Razina opisa \\ Količina i nosač zapisa \\ Sadržaj}

\section{Plan sređivanja}

HR-DAPA-257/3.5

Isplate plaća i ostalih primanja

1947-1952

Podserija

4 kutije, $0,40 \mathrm{~d} / \mathrm{m}$

Gradivo sadrži podatke o osobnim dohodcima, odnosno njihovim isplatama radnicima ŽT-a Pula i kontrolne osobne listove zaposlenih radnika, kojima je praćen tijek zaposlenja radnika i stanje obračuna $i$ isplata osobnih izdataka. Gradivo je sadržajno razvrstano unutar podserije i složeno kronološki. Kontrolni osobni listovi razvrstani su abecedno i premda su najvećim dijelom numerirani, unutarnji poredak slijedi abecedu jer je numeracija nedosljedna, duplirana i sl. te uzevši u obzir činjenicu da gradivo Fonda nije u potpunosti sačuvano i pohranjeno u DAPA-i, ovaj je način sređivanja u najvećoj mjeri osigurao unutarnju strukturu gradiva ove podserije. 


\section{Inventarni popis gradiva}

\begin{tabular}{|c|c|c|c|c|}
\hline Signatura & Sadržaj/naslov gradiva & Raspon godina & Teh. jedinica & Napomena \\
\hline 3.5.1. & $\begin{array}{l}\text { Knjiga evidencije deponiranih plaća rad- } \\
\text { nika ŽT-a Pula }\end{array}$ & 1949 & Kut. 79 & \\
\hline 3.5.2. & $\begin{array}{l}\text { Isplate plaća - platni popisi, nalozi za } \\
\text { isplate }\end{array}$ & 1950 & & \\
\hline \multirow[t]{4}{*}{ 3.5.3. } & $\begin{array}{l}\text { Podatci o zaradi - kontrolni osobni listo- } \\
\text { vi isplata }\end{array}$ & $1947-1952$ & & \\
\hline & $\begin{array}{l}\text { Podatci o zaradi - kontrolni osobni listo- } \\
\text { vi isplata } \mathrm{A}-\mathrm{E}\end{array}$ & $1947-1952$ & Kut. 80 & \\
\hline & $\begin{array}{l}\text { Podatci o zaradi - kontrolni osobni listo- } \\
\text { vi isplata } \mathrm{F}-\mathrm{N}\end{array}$ & $1947-1952$ & Kut. 81 & \\
\hline & $\begin{array}{l}\text { Podatci o zaradi - kontrolni osobni listo- } \\
\text { vi isplata } \mathrm{O}-\check{Z}\end{array}$ & $1947-1952$ & Kut. 82 & \\
\hline
\end{tabular}




\section{SAŽETAK \\ Sumarno-analitički inventar fonda Željeznički tehnikum Pula 1947. - 1953.}

Fondom HR-DAPA-257 obuhvaćeno je gradivo nastalo djelovanjem Željezničkoga tehnikuma u Puli u razdoblju od 1947. do 1953. godine. Po završetku rata usmjeravaju se napori za stvaranje temelja buduće obnove ratom opustošene zemlje, pri čemu je posebno izražena potreba za stvaranjem jezgre stručnih, obrazovanih kadrova. S tim je ciljem njihovo osposobljavanje bilo izrazito važna zadaća kojoj se pristupalo odgovorno. Formiranjem Željezničkoga tehnikuma, kao obrazovne i odgojne ustanove, napravljen je konkretan iskorak u tom smjeru jer su u toj ustanovi stvarani stručni, deficitarni kadrovi za potrebe željeznice. Uzevši u obzir činjenicu da je prometna povezanost općenito, te u tom smislu i izgrađena željeznička infrastruktura, preduvjet pokretanja obnove zemlje i uspostave gospodarskih i industrijskih tijekova, ne čudi ambiciozan plan izobrazbe potrebnih kadrova što je rezultiralo stvaranjem Željezničkoga tehnikuma. Na razini Fonda pružene su informacije o specifičnim povijesnim okolnostima na području Istre te konkretno i samoga grada Pule, a što je utjecalo na djelovanje stvaratelja, potom informacije o stvaratelju te o samom gradivu.

Arhivističkoj se obradi Fonda pristupilo 2014. godine. Na nižim je razinama gradivo raspoređeno sukladno sadržaju, području djelatnosti ili funkciji koju su spisi prikazivali. Prilikom sređivanja gradivo je raspoređeno na serije: Rad i poslovanje, Kadrovski poslovi i Financijsko poslovanje.

\section{SUMMARY \\ The Summary and Analytical Inventory of the Fonds of the Railroad Technical School in Pula 1947 - 1953}

The HR-DAPA-257 Fonds covers archives created by the Željeznički tehnikum - Railroad Technical School in Pula in the period from 1947 to 1953. At the end of the war efforts were made to create the foundations for the future reconstruction of the war-torn country, with particular emphasis on the need to create the core of expert and educated professionals. Consequently, their training was a very important task that was approached very seriously. By forming the Railroad Technical School as an educational institution, a concrete step forward was made in this direction, as the school provided experts in professions with skills shortages to work on the railways. Taking into account the fact that general transport connections, including the built railway infrastructure, were the prerequisite for launching the reconstruction of the country and the establishment of economic and industrial flows, the ambitious plan of education of the necessary professionals does not come as a surprise, nor does the establishment of the Railway Technical School. At the level of the Fonds, information was first given on specific historical circumstances in Istria and in the City of 
Pula in particular, which influenced the creator's activity; followed by information on the creator and on the archives.

The archival processing of the Fonds commenced in 2014. At the lower levels, the material was distributed according to the content, area of activity or function that the records showed. While it was being arranged, the material was divided into series: Work and Operation, Personnel and Financial Operations.

\section{RIASSUNTO \\ Inventario sommario analitico del fondo Željeznički tehnikum Pula (Scuola superiore tecnica di Pola) 1947 - 1953}

Il fondo HR-DAPA-257 comprende il materiale prodotto nel corso dell'attività del Željeznički tehnikum u Puli (Scuola superiore tecnica di Pola) nel periodo tra il 1947 e il 1953. Alla fine della guerra furono fatti molti sforzi incentrati sulla costruzione delle basi per la ricostruzione futura del paese devastato dalla guerra, tra cui spicca il bisogno di produrre un nucleo di personale altamente qualificato e istruito. Questo obiettivo fu affrontato con molta responsabilità. Con la costituzione della Scuola superiore tecnica Željeznički tehnikum, quale istituzione educativa e istruttiva, fu fatto un concreto passo in avanti in questa direzione in quanto l'istituzione produceva personale altamente qualificato, allora carente, per i bisogni delle ferrovie. Prendendo in considerazione il fatto che i collegamenti di trasporto in generale, e in questo senso anche la costruita infrastruttura ferroviaria, rappresentano il presupposto per l'avviamento della ricostruzione del paese e per la produzione dei flussi economici ed industriali, non sorprende il piano ambizioso relativo all'istruzione del personale necessario che ha come risultato l'istituzione della scuola Željeznički tehnikum. Al livello del Fondo sono state fornite informazioni relative alle specifiche circostanze storiche nel territorio dell'Istria e della città di Pola il che ha influenzato l'attività del soggetto produttore, inoltre, informazioni sul soggetto produttore e sul materiale stesso.

All'indagine archivistica del Fondo si è accesso nel 2014. Ai livelli minori il materiale è stato classificato in base al contenuto, all'ambito dell'attività o alla funzione che gli atti rappresentavano. Durante la sistematizzazione il materiale è stato diviso in serie: Lavoro e attività, Gestione del personale e Attività finanziarie. 